\title{
Perancangan Database Online 3D Grafis untuk Pembuatan Gambar Produksi Kapal
}

\author{
Zul Harris Olivianto dan Triwilaswandio Wuruk Pribadi \\ Departemen Teknik Perkapalan, Fakultas Teknologi Kelautan, Institut Teknologi Sepuluh Nopember (ITS) \\ e-mail: triwilas@na.its.ac.id
}

\begin{abstract}
Abstrak-Tujuan utama studi ini adalah merancang sistem aplikasi komputer database online untuk dapat menunjang engineer dalam pembuatan gambar produksi kapal. Pertama, dilakukan observasi terhadap proses pembuatan gambar produksi kapal yang dilakukan dengan penggunaan aplikasi grafis komputer berbasis 3D. Kedua, dilakukan perancangan sistem database online 3D grafis dengan melakukan pembuatan mockup. Ketiga, dilakukan uji coba sistem database dengan melakukan pembuatan gambar produksi dari sistem database untuk mengetahui kekurangan dan kelebihan dari sistem database yang telah dirancang. Penelitian ini memaparkan teknis pembuatan model 3D dan gambar produksi kapal serta melakukan analisis untuk membuat sistem database online 3D grafis. Database online yang dibuat telah dilengkapi data-data grafis 3D berupa contoh part-part konstruksi kapal dan outfitting seperti kontruksi pembujur, konstruksi melintang, pipa, serta plat-plat yang kemudian dapat diunggah dan diupdate oleh engineer untuk dapat menunjang kinerja engineer. Berdasarkan analisis yang dilakukan, pembuatan model 3D kapal dan gambar produksi kapal dengan aplikasi berbasis 3D dapat dilakukan lebih mudah dan cepat dengan dilakukan pembuatan sistem penunjang berupa sistem database/library berbasis internet.
\end{abstract}

Kata Kunci-grafis 3D, gambar produksi, aplikasi 3D.

\section{PENDAHULUAN}

$\mathrm{P}$ ERKEMBANGAN teknologi pada industri perkapalan berkembang sejalan dengan perkembangan teknologi komputer mulai dari proses desain sampai proses pembangunannya. Untuk proses desain kapal, software canggih komputer sudah mulai banyak digunakan untuk memudahkan proses perhitungan sampai pembuatan gambar karena tingkat presisi yang lebih baik. Software-software tersebut mempunyai banyak keunggulan, salah satunya adalah dalam hal pembuatan gambar 2 dimensi/3 dimensi yang biasa dikenal dengan Computer Aided Design (CAD). Software-software tersebut juga terus berkembang salah satunya dengan melakukan integrasi jaringan komputer yang mampu membagi pekerjaan desain menjadi beberapa bagian tetapi tetap saling berkaitan dan tersimpan dalam satu database server. Software tersebut memiliki beberapa kelemahan, salah satunya adalah mahalnya investasi yang harus dikeluarkan untuk pengembangan dan pengadaan hardware dan software-software tersebut.

Pada saat sekarang ini, persaingan antar pengembang software menyebabkan munculnya software yang relatif lebih murah dan lebih canggih dibandingkan softwaresoftware sebelumnya. Aplikasi yang akan digunakan merupakan CAD software berbasis 3D yang diproduksi oleh Dassault Systems. Aplikasi ini mampu memberikan visualisasi gambar 3D yang memuaskan dan cara penggunaannya yang relatif mudah. Disamping memiliki kelebihan, aplikasi ini memiliki kekurangan yaitu rumit dan panjangnya proses pembuatan model dengan menggunakan aplikasi grafis komputer.

Dalam studi ini, penulis akan melakukan perancangan dan analisis penggunaan database untuk membuat gambar produksi kapal menggunakan salah satu software desain kapal. Dikarenakan database pada aplikasi ini dapat dilakukan update, maka lama-kelamaan database menjadi lebih lengkap dan bervariasi. Pembuatan gambar produksi dengan database memungkinkan proses pemodelan dilakukan tidak dari awal sehingga mempercepat dan mempermudah praktisi dan lembaga pendidikan dalam melakukan pembuatan model kapal dan gambar produksi kapal dengan aplikasi grafis komputer.

\section{STUDI LITERATUR}

\section{A. Tahapan Proses Desain Kapal}

Pembangunan kapal adalah industri yang bergerak untuk menghasilkan produk (seperti kapal, bangunan lepas pantai, pabrik terapung, dsb) untuk pemesan. Pada umumnya produk yang dibangun harus mengikuti dan memenuhi spesifikasi khusus yang diberikan oleh pemilik/pemesan. Kondisi ini bahkan berlaku pada kondisi dimana kapal yang akan dibangun serupa dengan kapal yang sedang dibangun (Sister Ship). Proses secara keseluruhan sangat bervariasi tergantung dari pelanggan yang terlibat, tetapi pada umumnya proses pembangunan kapal terdiri dari beberapa tahapan yang dapat diringkas sebagai berikut [1]:

- Owner's requrements

- Preliminary/concept design

- Contract design

- Bidding/contracting

- Detail design and planning

- Construction

Dalam pembuatan kapal diperlukan beberapa tahapan proses produksi yang terdiri dari [2]:

- Persiapan produksi: perancangan dan persiapan gambar kerja, penyimpangan dan pemeriksaan material, persiapan tenaga kerja dan lain-lain.

- Mould Loft: pembuatan mal atau gambar produksi

- Fabrikasi: identifikasi material, marking, cutting dan forming

- Sub Assembly/Assembly: fitting dan welding komponen dasar dari seksi/blok

- Erection: penggabungan seksi/blok menjadi kapal 


\section{B. Manajemen Pembangunan Kapal}

Proses pembangunan sebuah kapal yang begitu rumit memerlukan manajemen khusus dalam proses pembangunannya. Group Technology dapat didefinisikan sebagai logika penataan dan pengurutan berbagai kegiatan operasional perusahaan dalam upaya untuk mendapatkan keuntungan dari penerapan produksi masal sampai produk variasi tinggi dengan kuantitas campuran [3].

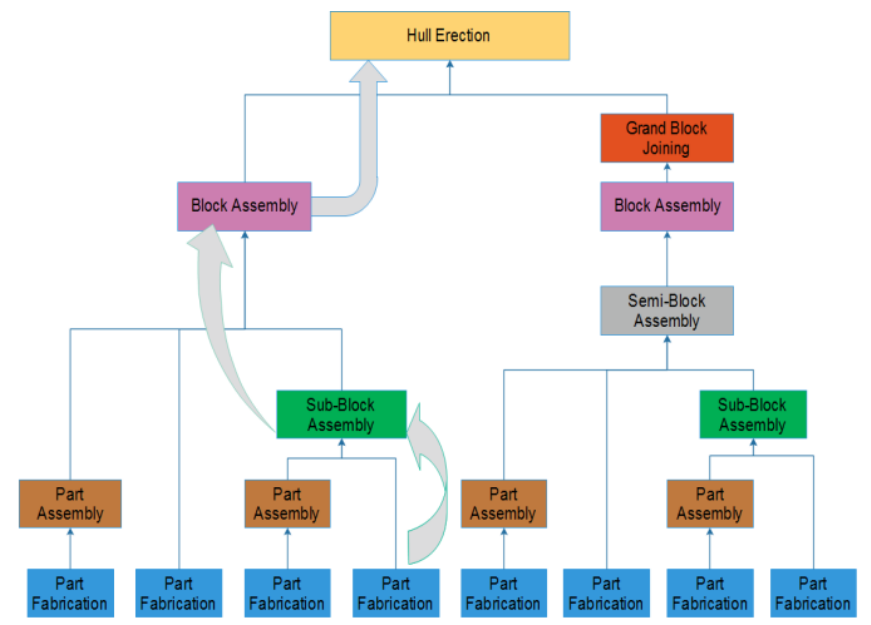

Gambar 1. Tampilan tingkatan hull block construction method (HBCM)

Dalam hal ini akan dipaparkan beberapa teknologi manajemen pembangunan kapal dimana kapal dapat dibagi menjadi beberapa bagian ( group) proses pekerjaan untuk memudahkan proses pembangunan yang disebut Work Break Down Structures. Dalam proses pembagian tersebut pada umumnya dapat digolongkan menjadi 2 yakni SystemOriented Work Breakdown Strucure dan Product-Oriented Work Breakdown Structure [4].

\section{Computer Aided Design (CAD)}

Computer-aided design (CAD) adalah penggunaan sistem komputer atau workstation untuk membantu pembuatan, modifikasi, analisis, atau optimalisasi desain. Perangkat lunak CAD digunakan untuk meningkatkan produktivitas perancang, meningkatkan kualitas desain, memperbaiki komunikasi melalui dokumentasi, dan membuat database dalam proses manufaktur. Output dari CAD umumnya berupa file elektronik untuk media cetak, mesin, atau operasi manufaktur lainnya [5].

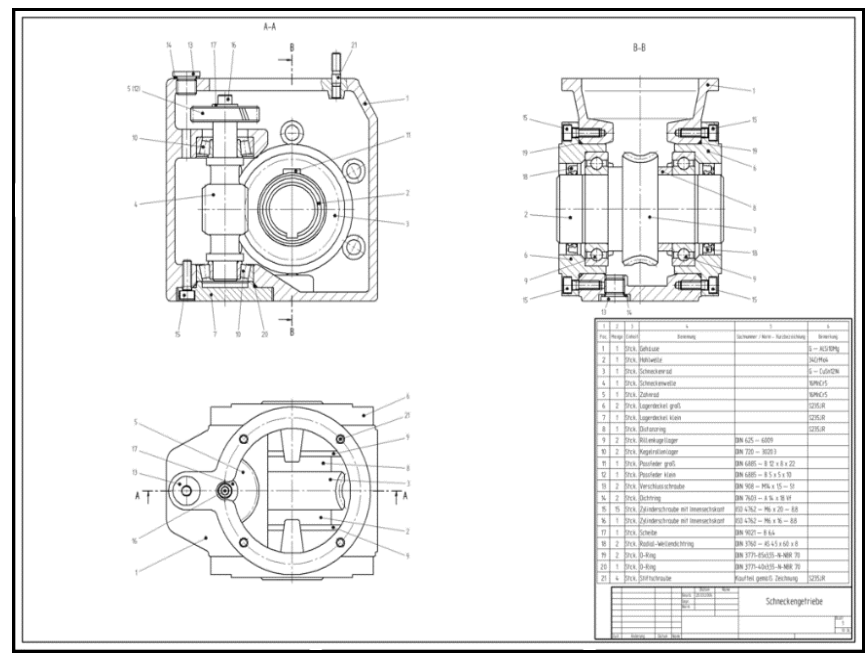

Gambar 2. Contoh hasil CAD 2 dimensi
Gambar 1. menggambarkan contoh hasil penggambaran gambar teknik dengan menggunakan aplikasi perangkat lunak CAD (Computer Aided Design). Dapat diketahui bahawa gambar teknik memerlukan tidak hanya sekedar penggambaran bentuk benda (objek) tetapi juga informasi detail spesifikasi dimensi, jenis bahan, dll. Dalam perkembangannya, perangkat lunak saat ini tidak hanya dapat digunakan untuk menggambarkan objek dalam ruang 2 dimensi tetapi juga dalam ruang 3 dimensi [6].

\section{D.Pengenalan Aplikasi Berbasais 3D}

Aplikasi berbasis 3D yang digunakan merupakan sebuah perangkat lunak CAD yang diproduksi oleh Dassault Systems. Kegunaan aplikasi ini adalah sebagai media untuk merancang bagian permesinan atau susunan bagian permesinan yang memiliki wujud assembling dalam tampilan 3-Dimensi guna menggambarkan bagian sebelum bagian utamanya dibuat atau tampilan gambar 2-Dimensi untuk desain permesinan. Aplikasi ini dikenalkan pada masyarakat umum sekitar tahun 1995 yang dapat menyaingi pendahulunya, karena harga solidworks terbilang murah. Aplikasi berbasis 3D sendiri sudah diciptakan pada tahun 1993 oleh Jon Hirstick dan terus dikembangkan dengan merekrut beberapa insinyur untuk mendirikan perusahaan software CAD 3D [7].

\section{METODOLOGI PENELITIAN}

\section{A. Studi Literatur}

Dalam pengerjaan studi ini diperlukan teori-teori dasar yang dapat mendukung pengerjaan studi ini yang didapat dari sumber referensi yang berkaitan dengan proses pembuatan model 3D kapal dan pembuatan gambar produksi kapal, diantaranya;

1) Proses Desain Kapal

2) Teknologi Produksi Kapal

3) Manajemen Pembangunan Kapal

4) Computer Aided Design (CAD)

5) Aplikasi Grafis 3D

6) Pembuatan Gambar Produksi

\section{B. Pengumpula Data}

Untuk membuat model 3D dengan aplikasi ini diperlukan data-data untuk menjadi acuan pembuatan model yang sesuai dengan desain. Data-data yang diperlukan antara lain ;

1) Ukuran utama model kapal

2) Body Plan model kapal

3) Gambar detail desain (Detail Drawing)

4) Construction Profile

\section{Pembuatan Gambar Produksi Kapal Saat Ini}

Pengujian pembuatan model 3D kapal dilakukan saat melakukan pembuatan model 3D kapal dan gambar produksi kapal untuk mengetahui kemampuan dan kelayakan aplikasi berbasis 3D tersebut dalam proses pembuatan model dan gambar produksi. Pembuatan gambar dilakukan dengan melakukan pengambilan master gambar part pada database dan melakukan assamble sehingga terbentuk panel dan block yang kemudian akan digunakan untuk menghasilkan gambar produksi. 


\section{D.Perancangan Sistem Database Online}

Perancangan aplikasi dilakukan dengan cara sebagai berikut:

1) Pembuatan mock up aplikasi dalam Microsoft Word

2) Desain interface atau tampilan pada website

3) Perancangan database online berbasis website

4) Pengisian konten database awal berupa model part-part bagian konstruksi kapal prototype

\section{PEMODELAN GAMBAR PRODUKSI KAPAL SAAT} INI

\section{E. Data-Data Kapal}

Sebelum pemodelan gambar 3 dimensi dilakukan, dibutuhkan beberapa input data desain 2 dimensi berupa desain konstruksi pada setiap part yang akan dikerjakan. Diantaranya adalah:

- Kapasitas muatan kapal kontainer

- Ukuran ukuran utama kapal container

- General Arrangement

- Construction Profile

- Mid Ship Section

\section{F. Prosedur Pembuatan Gambar Produksi}

Gambar produksi merupakan gambar yang digunakan untuk menggambarkan proses pengerjaan pada bengkel mulai dari fabrikasi, perakitan part menjadi suatu panel, penggabungan panel menjadi blok, sampai urutan penggabungan grand block. Gambar produksi umumnya dimulai dengan melakukan pembagian block yang memperhitungkan beberapa faktor seperti jarak gading, construction profile, kapasitas berat crane, panjang plat kulit dan bukaan kulit yang biasa disebut dengan block devision. Kemudian , pembuatan gambar produksi dilakukan dengan cara melakukan breakdown kapal dari model 3d. Maka dari itu diperlukan model 3 Dimensi dari kapal yang akan dibuat. Gambar 3. menggambarkan alur proses pembuatan gambar produksi kapal dengan menggunakan aplikasi berbasis $3 \mathrm{~d}$.

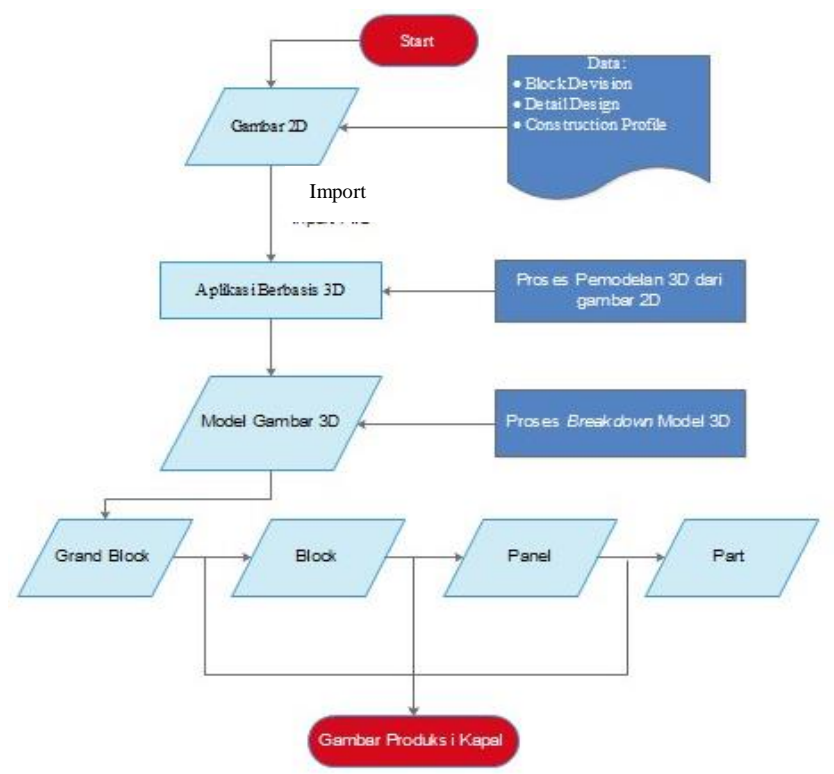

Gambar 3. Bagan alur pembuatan gambar produksi kapal.

\section{G.Pembuatan Model 3D}

Pembuatan model 3D dari data di atas dapat dilakukan dengan beberapa metode, yaitu diantaranya pembuatan model 3D dari gambar sketch 2D yang diimport ke aplikasi tersebut atau langsung dari rencana garis (Body Plan) yang yang diimport yang akan membentuk langsung model kapal 3D secara pejal yang dapat dipotong sesuai ukuran. Dari proses tersebut kemudian akan dapat dilakukan pembuatan gambar produksi kapal dengan fitur drawing yang ada dalam aplikasi saat melakukan proses assembly. Pembuatan gambar meliputi beberapa fitur dari aplikasi berbasis 3D diantaranya:

- Fungsi Sketch

- Fungsi Extrude

- Fungsi Pattern

- Fungsi Thin

Berikut contoh pengerjaan fungsi extrude dalam aplikasi grafis berbasis 3D dalam pembuatan model 3D yang dapat digambarkan para Gambar 4:

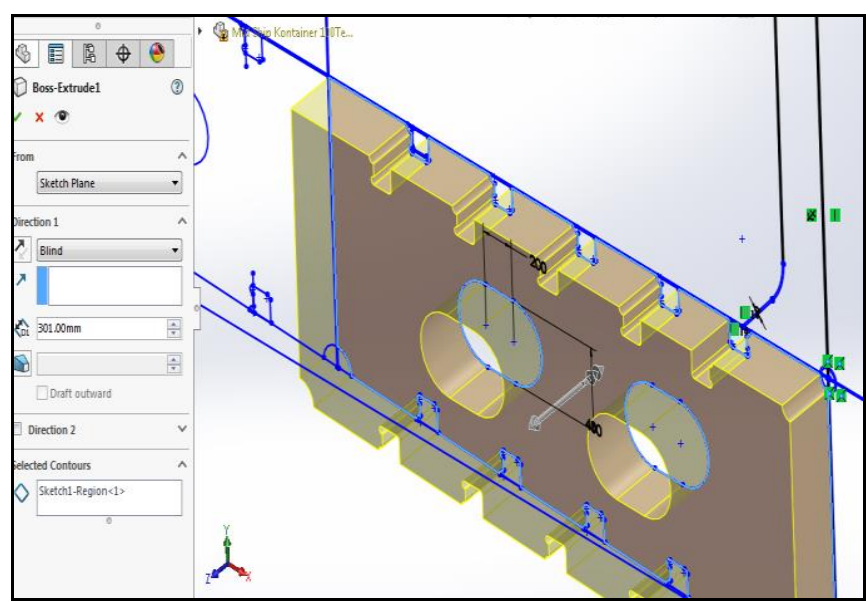

Gambar 4. Tampilan pengaturan fungsi extrude

\section{H.Pembuatan Gambar Produksi}

Pebuatan gambar produksi dilakukan dengan melakukan proses pemecahan/pemisahan dari gambar 3D yang sudah di buat dengan mengikuti alur pembagian pengerjaan hull production. Pada tahap ini diperlukan data berupa rencana pembagian blok (block devision) untuk membagi kapal menjadi beberapa blok besar. Untuk merancang / membuat rencana pembagian blok diperlukan data diantaranya data pemilihan material (panjang lajur plat), general arrangement, dan konstruction profile. Setelah perencanaan pembagian blok didapat, dilakukan pembagian kesatuan kapal dalam bentuk model 3D ke beberapa bagian plane fiew atau dapat dimulai dengan membuat model 3D dari part terkecil kemudian menggunakan fungsi assembly untuk merakit menjadi bagian yang lebih besar. 


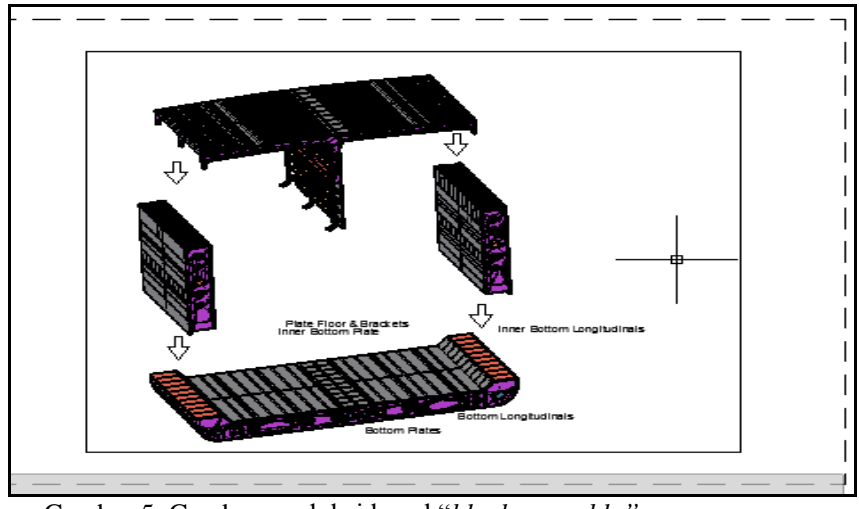

Gambar 5. Gambar produksi kapal "block assembly"

Gambar menggambarkan hasil contoh gambar produksi yang menggambarkan proses penggabungan blok menjadi grand block (Erecting) dengan menggunakan aplikasi grafis komputer.

\section{PERANCANGAN SISTEM DATABASE ONLINE 3D GRAFIS}

\section{A. Kerangka Sistem Database}

Setelah melakukan pengamatan dan penggunaan aplikasi sejenis yang memiliki sistem penyimpanan dan penyebaran data, dapat dilakukan penyusunan konsep kerangka sistem penyimpanan dan penyebaran data (Database) yang dapat dipaparkan seperti Gambar 4. di bawah ini ;

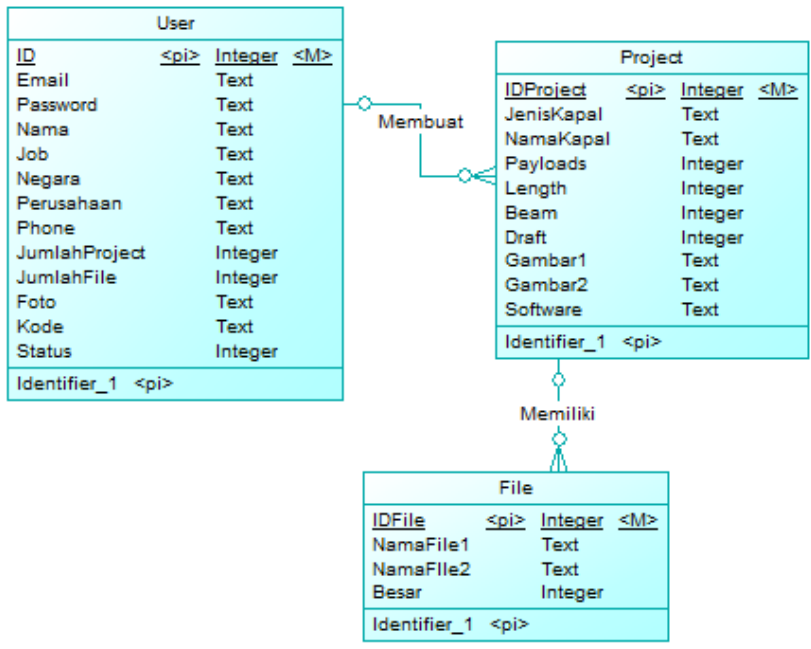

Gambar 6. Gambar conceptual data model

CDM atau Conceptual Data Model digunakan menggambarkan secara detail struktur database dalam bentuk logika. Struktur ini bersifat independen terhadap semua software yang maupun struktur database apapun. CDM berikutnya akan menjadi panduan pembuatan PDM atau Physical Data Model. Database yang digunakan adalah mysql, bahasa pemrograman yang digunakan adalah php, javascript, html dengan menggunakan framework codeigniter.

\section{B. Perancangan Mock Up dan Interface Sistem Database Online}

Tampilan sistem dibuat dengan basis website seperti 3DWarehouse untuk memudahkan para user saling membagi dan menggunakan gambar yang akan user gunakan/buat.
Tampilan website dirancang sedemikian rupa agar menarik dan mudah untuk digunakan oleh user, berikut adalah rancangan tampilan awal website yang akan dibuat:

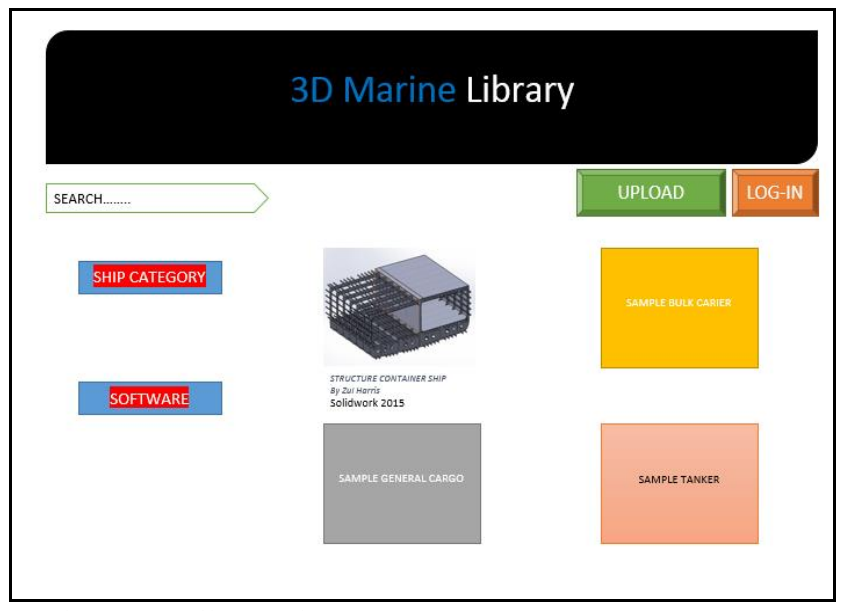

Gambar 7. Tampilan mock up

Gambar 7 menampilkan rancangan awal tampilan website yang akan dibuat. Tampilan awal memiliki beberapa pilihan fungsi/fitur yang tidak rumit dan memudahkan bagi para user diantara terdapat pilihan fungsi ;

- Pencarian

- Kategori kapal

- Kategori software

- Login

- Sign Up

- Upload

- Posting database

\section{Hasil Perancangan Database Online 3D Grafis}

Setelah dilakukan pembuatan mockup, pembuatan sistem database dilakukan dengan penyusunan urutan-urutan mockup dengan dan penggabungan entitas tampilan serta penyusunan ruang database untuk mengisi data gambar berbasis 3D. Susunan kerangka entitas disesuaikan dengan Physical Data Model yang telah disusun sebelumnya. Berikut merupakan uji coba halaman website sebagai sistem database.

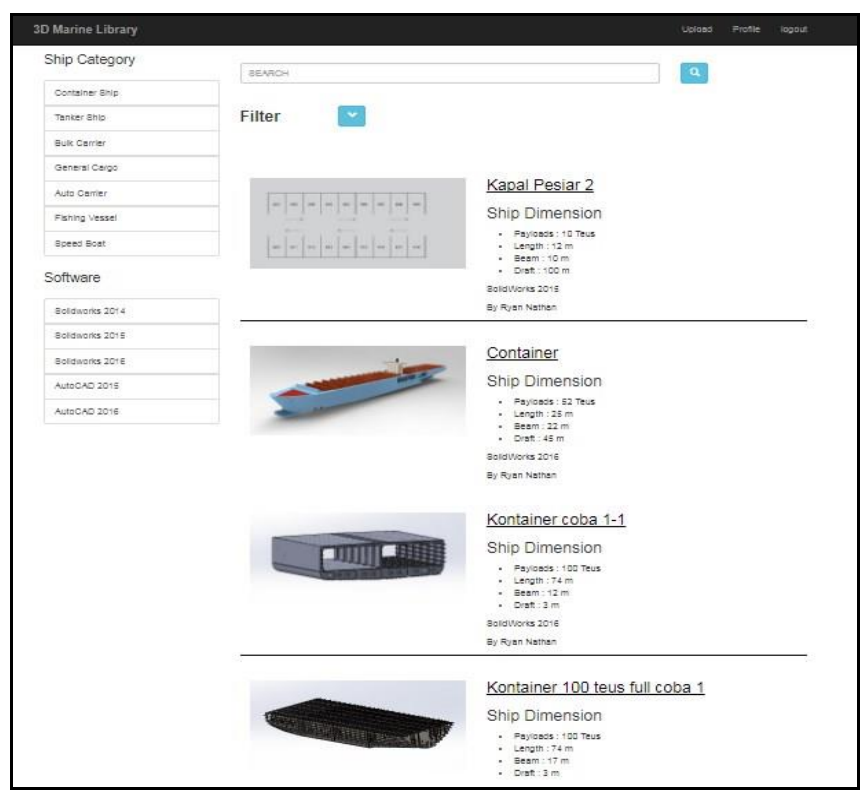

Gambar 8. Tampilan database online berbasis website 


\section{PENGUJIAN SISTEM DATABASE ONLINE UNTUK PEMBUATAN GAMBAR PRODUKSI}

\section{D.Prosedur Pemodelan 3D Kapal}

Pembuatan model 3D dari data di atas dapat dilakukan dengan beberapa metode, yaitu diantaranya pembuatan model 3D dari gambar sketch 2D yang diimport ke aplikasi tersebut atau langsung dari rencana garis (Body Plan) yang yang dimport yang akan membentuk langsung model kapal 3D secara pejal yang dapat dipotong sesuai ukuran. Pada praktik pengerjaannya, metode tersebut masih dirasa memerlukan waktu cukup lama untuk membuat model gambar 3D. Dalam penelitian ini akan dilakukan penggambaran dilakukan dengan mengambil model gambar part berbentuk 3D dari database yang kemudian dilakukan proses assembly sehingga membentuk panel dan block tanpa menggambar / membuat model part 3D dari awal. Dari proses tersebut kemudian akan dapat dilakukan pembuatan gambar produksi kapal dengan fitur drawing yang ada dalam aplikasi saat melakukan proses assembly.

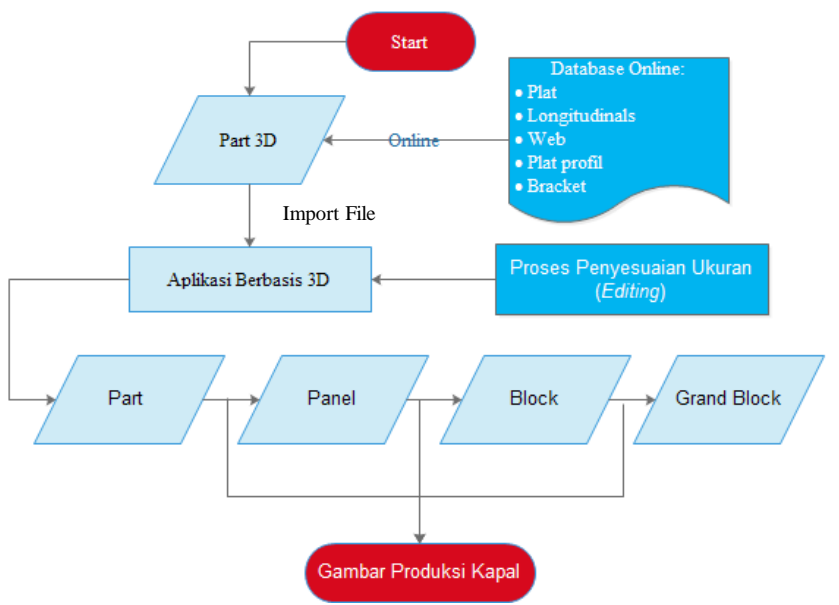

Gambar 9. Alur pembuatan gambar produksi dengan sistem database online $3 \mathrm{~d}$ grafis

\section{E. Konten Database Online 3D Grafis}

Database yang akan digunakan untuk menggambar model didapat dari part-part berbentuk 3D dari model part 3D kapal lain yang serupa dengan ukuran yang akan disempurnakan dan disesuaikan dengan kebutuhan desain baru. Part tersebut akan digunakan dalam proses assembly untuk membentuk suatu panel dengan fungsi "input new part" yang sebelumnya dilakukan pengubahan ukuran sesuai yang dibutuhkan serta melakukan pengaturan koordinat lokasi objek part tersebut.

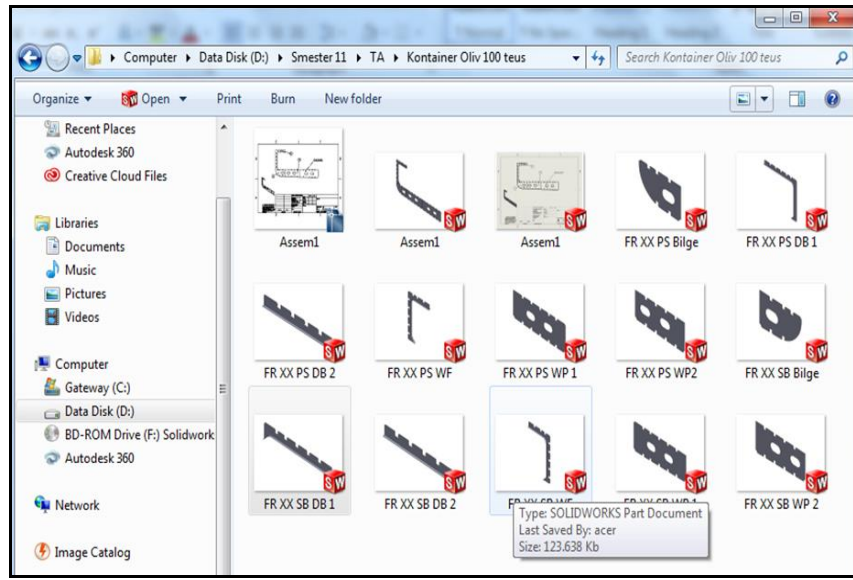

Gambar 10. Tampilan Konten Database 3D Grafis

\section{F. Pembuatan Gambar Produksi Kapal}

Fitur assembly pada aplikasi berbasis 3D yang digunakan merupakan salah saatu fitur pembuatan gambar 3D pada file baru (New File) dimana pemodelan dilakukan dengan proses penggabungan beberapa model 3 dimensi berupa file part menjadi satu kesatuan produk, dalam hal ini berupa seksi panel.

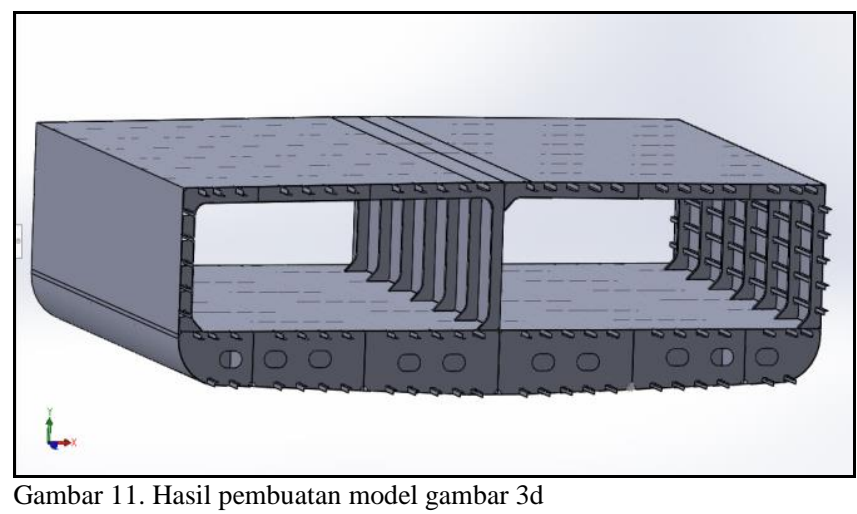

Gambar di atas menggambarkan tampilan model 3d yang dibuat dari database dengan menggunakan fitur assembly dimana dari proses assembly tersebut didapat gambar produski kapal. Berikut hasil dari analisa sistem dengan menunjukkan kelebihan dan kekurangan dari sistem: Tabel 1.

Analisis pembanding sistem

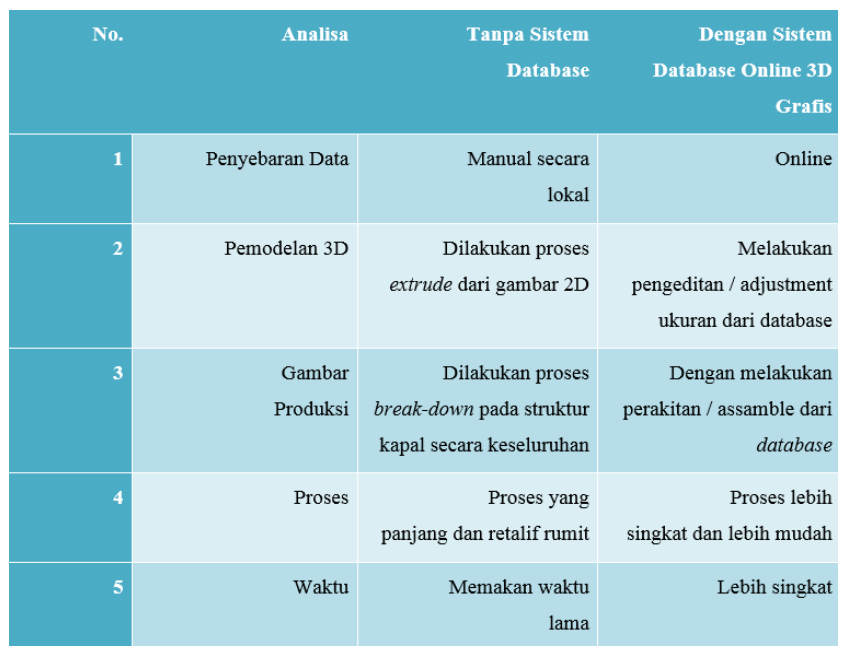




\section{G. Uji Coba Sistem Database Online 3D Grafis}

Untuk menguji Database Online 3D Grafis dilakukan pengujian sistem database yang telah dibuat oleh beberapa praktisi terkait yang memiliki latar belakang kemampuan untuk menggambar gambar produksi kapal dan konstruksi kapal dengan menggunakan aplikasi grafis komputer oleh beberapa koresponden yang memiliki latarbelakang dibidang perkapalan.

\section{KESIMPULAN/RINGKASAN}

1) Pembuatan gambar produksi saat ini dilakukan dengan proses yang cukup panjang menggunakan aplikasi grafis dimana pemodelan dapat dilakukan dengan dua cara, diantaranya melakukan export-inport antar aplikasi, dan melakukan pemodelan dari gambar 2D menjadi 3D. Proses export-inport dilakukan dengan melakukan perpindahan file antar aplikasi grafis yang berbeda kemudian melakukan proses pembentukan struktur badan kapal yang kemudian dilakukan proses break-down untuk menghasilkan gambar produksi kapal.

2) Perancangan database online 3D grafis dilakukan dengan melakukan konsep penyebaran data, pembuatan mock up, desain interface, pembuatan database, pembuatan website dan melakukan pengisian database dengan file aplikasi grafis. Dalam database berbentuk website tersebut, pengguna memiliki kewenangan untuk melakukan unduh dan unggah file grafis berupa model grafis 3D yang dapat digunakan untuk menggambar gambar produksi kapal. Setelah pengguna melakukan unduh dan mengubah dimensi part yang akan digunakan untuk menggambar produksi kapal, pengguna dapat melakukan unggah hasil editan ke database sehingga seiring berjalan waktu database dapat berkembang dan data menjadi semakin bervariasi dan lengkap.

3) Kelebihan dari sistem database online 3D grafis ini adalah pembuatan gambar produksi yang dilakukan dengan melakukan pengubahan (edit) dimensi part yang digunakan akan mempersingkat waktu dan memudahkan proses pemodelan. Sistem ini memungkinkan para desainer tidak membuat/menggambar model dan gambar produksi dari awal karena pembentukan dilakukan dari database yang fungsinya seperti menambah fitur modeling dalam aplikasi grafis yang lebih terintegrasi untuk pembuatan model konstruksi kapal dan gambar produksi

\section{UCAPAN TERIMA KASIH}

Penulis mengucapkan terima kasih kepada Bapak Ir. Triwilaswandio Wuruk Pribadi, M.Sc. selaku dosen pembimbing beserta dosen dan karyawan di Departemen Teknik Perkapalan ITS yang telah membantu dan membimbing penelitian ini sampai terbitnya jurnal ini. Penulis mengucapkan terima kasih kepada Ayah dan Almarhumah Ibu tercinta yang telah membesarkan penulis atas do'a, kasih sayang, dukungan, dan bimbingannya yang tidak pernah berhenti.

\section{DAFTAR PUSTAKA}

[1] C. R. Storch, R. L., Hammond, P. C., Bunch, M. H., \& Moore Ship Production (2nd ed.). United State of America: Cornell Maritime Press, inc, 1995.

[2] Soejitno, "Teknik Reparasi Kapal dan Teknik Produksi," Fak. Teknol. Kelaut. - ITS, 1997.

[3] E. . Ranson, K.J. and Tupper, Basic Ship Theory (5th ed., Vol 1). Oxford: Butterworth-Heinemann, 2001.

[4] L. D. Okayama, Y., \& Chirillo, Product Work Breakdown Structure. Washington D.C: Dept. of Commerce, Maritime Administration in cooperation with Todd Pasific Shipyards Coorporation, 1980.

[5] K. L. Narayan, Computer Aided Design and Manufacturing. New Delhi, 2008.

[6] J. Pottmann, H., Brell-Cokcan, S., \& Wallner, Discrete Surface of Architectural Design. Wayback Machine, 2007.

[7] C. History, "Solidworks Coorporation," Solidworks Corporation, 2017. [Online]. Available: http://www.solidworks.com/sw/656_ENU_HTML.htm. 